\title{
TANTANGAN DAN HAMBATAN OTORITAS JASA KEUANGAN DALAM PENGAWASAN EQUITY CROWDFUNDING
}

\author{
Zevanya Emmanuela Issubagyo \\ E-mail: zevanyaei@gmail.com \\ Mahasiswa Fakultas Hukum Universitas Sebelas Maret Surakarta \\ Dona Budi Kharisma \\ E-mail: donabudikharisma@gmail.com \\ Dosen Fakultas Hukum Universitas Sebelas Maret Surakarta
}

\begin{abstract}
The purpose of this article is to determine the problems in the implementation of equity crowdfunding. This legal research uses descriptive empirical legal writing method by conducting a qualitative analysis of primary data and secondary data.. The result showed that there were obstacles inside the legal system as well as outside the legal system, including normative problems related to the Regulation of the Financial Services Authority Number 37/POJK.04/2018 about Funding Services through Stock Offerings based on Information Technology (Equity Crowdfunding), and non-normative problems that includeculture, infrastructure, systems, and the limited knowledge of the community. Therefore, the government, especially the Financial Services Authority, should revise the Financial Services Authority Regulation regarding equity crowdfunding to be more optimal.
\end{abstract}

Keywords: Problems; Otoritas Jasa Keuangan; Equity Crowdfunding

\begin{abstract}
Abstrak
Tujuan artikel ini untuk mengetahui problematika dalam pelaksanaan equity crowdfunding. Jenis penelitian hukum ini adalah hukum empiris bersifat deskriptif, dengan analisis secara kualitatif pada data primer dan data sekunder. Hasil dalam penelitian ini adalah adanya hambatan dalam sistem hukum maupun di luar sistem hukum yang menghambat terlaksananya equity crowdfunding di Indonesia, diantaranya problematika normatif yang terdapat di dalam Peraturan Otoritas Jasa Keuangan Nomor 37/POJK.04/2018 tentang Layanan Urun Dana melalui Penawaran Saham Berbasis Teknologi Informasi (Equity Crowdfunding), dan problematika non normatif yang mencakup budaya, infrastruktur, sistem, dan keterbatasan pengetahuan masyarakat. Oleh karena itu, pemerintah khususnya Otoritas Jasa Keuangan seharusnya merevisi Peraturan Otoritas Jasa Keuangan mengenai equity crowdfunding agar penyelenggaraan equity crowdfunding lebih optimal.
\end{abstract}

Kata Kunci: Problematika; Otoritas Jasa Keuangan; Equity Crowdfunding

\section{A. Pendahuluan}

Perkembangan kegiatan wirausaha yang diimbangi dengan pesatnya kemajuan teknologi di Indonesia, membuka peluang bagi bidang financial technology (fintech) yang memanfaatkan perkembangan teknologi berkembang dengan pesat. Perusahaan fintech equity crowdfunding menawarkan aplikasi yang bisa mempertemukan pemilik dana dengan start 
up atau UKM yang membutuhkan suntikan dana. Hal ini tentu membuka kesempatan bagi pelaku usaha start up atau UKM untuk mendapatkan pendanaan guna menjalankan bisnisnya. Sekaligus mencari alternatif pencarian dana di luar pasar modal dan perbankan. Sementara bagi pemilik dana, mereka bisa memiliki pilihan yang lebih luas untuk berinvestasi, di luar portofolio yang selama ini sudah ada di pasar finansial. Berdirinya fintech crowdfunding di Indonesia, tentunya diimbangi juga dengan adanya aturan yang berlaku agar melindungi pihak-pihak yang terlibat di dalamnya.

Peraturan Otoritas Jasa Keuangan Nomor 37/POJK.04/2018 tentang Layanan Urun Dana melalui Penawaran Saham Berbasis Teknologi Informasi (Equity Crowdfunding) mulai berlaku pada tanggal 31 Desember 2018. Dalam pelaksanaannya, banyak faktor yang menghambat terlaksananya equity crowdfunding di Indonesia, tidak menutup kemungkinan hambatan tersebut terjadi karena peraturan yang menjadi dasar terlaksananya equity crowdfunding belum mengatur secara ketat, dan masih terdapat celah untuk melakukan kecurangan atau perilaku yang menyebabkan kerugian bagi pihak lain yang terdapat di dalam equity crowdfunding.

Berdasarkan uraian di atas maka dalam artikel ini penulis mengkaji Tantangan dan Hambatan Otoritas Jasa Keuangan dalam Pengawasan Equity Crowdfunding.

\section{B. Metode Penelitian}

Penelitian ini merupakan penelitian empiris yang bersifat deskriptif. Pendekatan yang digunakan adalah pendekatan kasus. Sumber bahan hukum yang digunakan adalah bahan hukum primer dan sekunder. Teknik pengumpulan data yang digunakan adalah studi kepustakaan dan wawancara, dengan teknik analisis yang digunakan merupakan metode deduktif.

\section{Hasil Penelitian dan Pembahasan}

1. Problematika Normatif Peraturan Otoritas Jasa Keuangan Nomor 37/POJK.04/2018 tentang Layanan Urun Dana Melalui Penawaran Saham Berbasis Teknologi Informasi (Equity Crowdfunding), selanjutnya disebut POJK Equity Crowdfunding

a. Pasal 13 Ayat 1

Di dalam Pasal 13 POJK Equity Crowdfunding disebutkan bahwa:

1) Penyelenggara wajib memiliki:

a) Sumber daya manusia yang memiliki keahlian dan/atau latar belakang di bidang Teknologi Informasi; dan

b) Sumber daya manusia yang memiliki keahlian untuk melakukan reviu terhadap Penerbit

2) Penyelenggara harus meningkatkan kualitas sumber daya manusia melalui kegiatan urun pendidikan dan pelatihan yang mendukung pengembangan Layanan Urun Dana

Yang dimaksud "memiliki keahlian untuk melakukan reviu terhadap Penerbit" adalah memiliki baik sumber daya manusia yang memiliki latar belakang di bidang hukum untuk mereviu mengenai aspek legal Penerbit, maupun sumber daya manusia yang memiliki latar belakang di bidang akuntansi untuk mereviu mengenai 
laporan keuangan Penerbit. Di dalam penjelasan pasal demi pasal POJK Equity Crowdfunding menjelaskan mengenai "keahlian dan/atau latar belakang di bidang Teknologi Informasi" tersebut dibuktikan dengan adanya sertifikat keahlian atau surat keterangan pengalaman kerja paling sedikit 1 (satu) tahun di bidang Teknologi Informasi. Sedangkan bukti Penyelenggara memiliki sumber daya manusia yang memiliki keahlian untuk mereviu Penerbit tidak dijelaskan dalam POJK ini.

Tidak menutup kemungkinan permohonan izin Pelaku Usaha Jasa Keuangan (selanjutnya disebut PUJK) yang mendaftarkan dirinya untuk menjadi Penyelenggara ditolak oleh OJK karena alasan perbedaan pemahaman. Hal ini merupakan sesuatu yang sangat esensial, mengingat sumber daya manusia yang dimiliki Penyelenggara ini merupakan salah satu penentu permohonan izin Penyelenggara diterima oleh OJK sekaligus sebagai penentu berjalannya dan berkembangnya Layanan Urun Dana yang dijalankan oleh Penyelenggara.

\section{b. Pasal 22 Ayat 3}

Di dalam Pasal 22 POJK Equity Crowdfunding disebutkan bahwa:

1) Penyelenggara yang telah memperoleh izin dan menyatakan tidak akan meneruskan kegiatan operasionalnya dapat mengembalikan izin kepada Otoritas Jasa Keuangan dengan menyampaikan:

1. suratpermohonan pengembalianizin dalambentukdan isisesuaidengan format Surat Permohonan Pengembalian Izin Sebagai Penyelenggara Layanan Urun Dana (Equity Crowdfunding) tercantum dalam Lampiran yang merupakan bagian yang tidak terpisahkan dari Peraturan Otoritas Jasa Keuangan ini; dan

2. surat pernyataan rencana penyelesaian terkait hak dan kewajiban Pengguna dalam bentuk dan isi sesuai dengan format Surat Pernyataan Rencana Penyelesaian Terkait Hak dan Kewajiban Pengguna tercantum dalam Lampiran yang merupakan bagian yang tidak terpisahkan dari Peraturan Otoritas Jasa Keuangan ini.

2) Otoritas Jasa Keuangan mencabut izin Penyelenggara paling lambat 20 (dua puluh) hari kerja setelah diterimanya surat pengembalian izin sebagaimana dimaksud pada ayat (1).

3) Pengembalian izin sebagaimana dimaksud pada ayat (1) tidak serta merta menghilangkan kewajiban dan tanggung jawab Penyelenggara terhadap Pengguna, dan pemenuhan peraturan perundang-undangan dan/atau keputusan Otoritas Jasa Keuangan yang belum dipenuhi yang timbul pada saat izin Penyelenggara belum dicabut sebagaimana dimaksud pada ayat (2).

Tidak adanya penjelasan lanjutan mengenai tanggung jawab Penyelenggara terhadap Pengguna dalam hal Penyelenggara tidak dapat meneruskan kegiatan operasionalnya dapat menimbulkan 2 macam permasalahan:

1) Tidak adanya standar atau syarat minimal penyusunan rencana pemenuhan hak dan kewajiban Pengguna dapat mengakibatkan tidak terpenuhinya perlindungan konsumen, karena rencana pemenuhan hak dan kewajiban Pengguna yang disusun oleh Penyelenggara dapat merugikan Pengguna khususnya Pemodal dalam equity crowdfunding. 
2) Tidak mewajibkan Penyelenggara untuk memberitahukan kepada para penggunanya bahwa Penyelenggara akan melakukan pengajuan pengembalian izin ke OJK. Penjelasan lebih lanjut mengenai tanggung jawab Penyelenggara ini seharusnya dijelaskan oleh OJK sebagai pedoman adanya perlindungan konsumen yaitu Pengguna Layanan Urun Dana. Hal ini menyimpangi ketentuan yang ada di dalam Pasal 12 Peraturan Otoritas Jasa Keuangan Nomor 1/POJK.07/2013 tentang Perlindungan Konsumen Sektor Jasa Keuangan, yang memuat:

1) PUJK wajib menginformasikan kepada Konsumen setiap perubahan manfaat, biaya, risiko, syarat, dan ketentuan yang tercantum dalam dokumen dan/atau perjanjian mengenai produk dan/atau layanan PUJK.

2) Informasi sebagaimana dimaksud pada ayat (1) wajib diberitahukan kepada Konsumen paling lambat 30 (tiga puluh) hari kerja sebelum berlakunya perubahan manfaat, biaya, risiko, syarat dan ketentuan atas produk dan/ atau layanan PUJK.

3) Dalam hal Konsumen tidak menyetujui perubahan terhadap persyaratan produk dan/atau layanan sebagaimana dimaksud pada ayat (1), maka Konsumen berhak memutuskan produk dan/atau layanan tanpa dikenakan ganti rugi apapun.

4) Dalam hal Konsumen sudah diberikan waktu untuk menyampaikan pendapatnya sebagaimana dimaksud pada ayat (2) dan Konsumen tidak memberikan pendapatnya maka PUJK menganggap Konsumen menyetujui perubahan tersebut.

Penjelasan dari Pasal tersebut bila dikaitkan dengan equity crowdfunding, khususnya dalam hal Penyelenggara melakukan permohonan pengembalian izin kepada OJK adalah Penyelenggara seharusnya memberitahukan kepada Penggunanya bahwa Penyelenggara akan melakukan permohonan pengembalian izin ke OJK dan disertai dengan rencana yang akan dilakukan untuk pemenuhan hak dan kewajiban Penggunanya. Apabila Penggunanya tidak menyetujui rencana yang disusun oleh Penyelenggara, maka Penggunanya dapat membatalkan atau mengembalikan saham yang telah dibelinya. Dalam hal Pemodal membatalkan atau mengembalikan saham yang telah dibelinya karena tidak setuju dengan rencana yang dibuat oleh Penyelenggara, Pemodal tidak dikenakan ganti rugi atau penalti.

\section{c. Pasal 39 Ayat 3}

Pada Pasal 39 POJK Equity Crowdfunding disebutkan bahwa:

1) Penerbit wajib menyampaikan laporan tahunan kepada Otoritas Jasa Keuangan dan mengumumkan kepada masyarakat melalui situs web Penyelenggara dan/ atau situs web Penerbit paling lambat 6 (enam) bulan setelah tahun buku Penerbit berakhir.

2) Selain memuat informasi sebagaimana diatur dalam undang-undang mengenai perseroan terbatas, laporan tahunan sebagaimana dimaksud pada ayat (1) wajib memuat informasi tentang realisasi penggunaan dana hasil penawaran saham melalui Layanan Urun Dana. 
3) Informasi mengenai realisasi penggunaan dana sebagaimana dimaksud pada ayat (2) wajib disampaikan dan diumumkan hingga dana hasil penawaran saham melalui Layanan Urun Dana telah habis digunakan.

Di dalam ayat 3 ini maupun di dalam penjelasan pasal demi pasal POJK Equity Crowdfunding, tidak disebutkan bahwa pemberian informasi tersebut wajib menggunakan bukti yang cukup. Kondisi seperti ini dapat memberikan celah kepada Penerbit yang nakal untuk menginformasikan penggunaan dana tidak sesuai dengan apa yang sesungguhnya terjadi. Selain itu keharusan menyertakan bukti dalam laporan realisasi penggunaan dana diperlukan Pemodal agar ikut mengawasi pertumbuhan Penerbit.

\section{d. Pasal 42 Ayat 1}

Pada Pasal 42 POJK Equity Crowdfunding disebutkan bahwa:

1) Pemodal yang dapat membeli saham melalui Layanan Urun Dana yaitu pihak yang memiliki kemampuan untuk membeli saham Penerbit, memiliki kemampuan analisis risiko terhadap saham Penerbit, dan memenuhi kriteria Pemodal sebagaimana diatur dalam Peraturan Otoritas Jasa Keuangan ini.

2) Kriteria Pemodal sebagaimana dimaksud pada ayat (1) meliputi:

a) setiap Pemodal dengan penghasilan sampai dengan Rp500.000.000,00 (lima ratus juta rupiah) per tahun, dapat membeli saham melalui Layanan Urun Dana paling banyak sebesar 5\% (lima persen) dari penghasilan per tahun; dan

b) setiap Pemodal dengan penghasilan lebih dari Rp500.000.000,00 (lima ratus juta rupiah) per tahun, dapat membeli saham melalui Layanan Urun Dana paling banyak sebesar 10\% (sepuluh persen) dari penghasilan per tahun.

3) Kriteria Pemodal dan batasan pembelian saham oleh Pemodal sebagaimana dimaksud pada ayat (2) tidak berlaku dalam hal Pemodal merupakan:

a) badan hukum; dan

b) pihak yang mempunyai pengalaman berinvestasi di Pasar Modal yang dibuktikan dengan kepemilikan rekening Efek paling sedikit 2 (dua) tahun sebelum penawaran saham.

Tidak adanya penjelasan lebih lanjut mengenai kriteria Pemodal yang memiliki kemampuan untuk membeli dan menganalisis saham Penerbit, dan kemampuan tersebut bersifat relatif, yang berarti pengertian "kemampuan Pemodal" tersebut antara OJK, Penyelenggara, maupun Pemodal itu sendiri berbeda-beda. Di dalam Pasal 42 Ayat 1 POJK Equity Crowdfunding, kemampuan untuk membeli dan menganalisis saham Penerbit berbeda dengan kriteria Pemodal, dilihat dari kata hubung "dan" dalam Ayat 1. Hal ini berarti, OJK tidak menjelaskan apa yang dimaksud dengan kemampuan pemodal untuk membeli dan menganalisis saham Penerbit, atau tidak menyebutkan bukti apa yang dapat diberikan oleh Pemodal untuk menunjukkan bahwa ia mampu membeli dan menganalisis saham Penerbit. Oleh karena itu pengertian "kemampuan untuk membeli dan menganalisis saham Penerbit" bersifat abstrak dan tidak dapat diuji. 


\section{e. Sanksi Pidana}

Pada POJK Equity Crowdfunding Pasal 66 Ayat 4, hanya menyebutkan bahwa Otoritas Jasa Keuangan dapat mengenakan sanksi administratif berupa:

1) Peringatan tertulis;

2) Denda yaitu kewajiban untuk membayar sejumlah uang tertentu;

3) Pembatasan kegiatan usaha;

4) Pembekuan kegiatan usaha;

5) Pencabutan izin usaha;

6) Pembatalan persetujuan; dan/atau

7) Pembatalan pendaftaran.

Seharusnya, sanksi pidana kepada PUJK karena melibatkan kepentingan umum Pemodal yang meletakkan dananya di platform Penyelenggara, karena sanksi administratif saja tidak cukup untuk menghukum PUJK yang melakukan kecurangan yang melibatkan dana Pemodal. Di dalam Pasal 65 POJK Equity Crowdfunding, disebutkan bahwa

Penyelenggara wajib menerapkan program anti pencucian uang dan pencegahan pendanaan terorisme di sektor jasa keuangan terhadap Pengguna sesuai dengan ketentuan peraturan perundang-undangan mengenai penerapan program anti pencucian uang dan pencegahan pendanaan terorisme.

Apabila selanjutnya Penerbit terbukti melakukan pencucian uang maupun pendanaan terorisme, maka seharusnya Penerbit dan Penyelenggara diberi sanksi pidana. Penyelenggara dapat diseret dalam pengenaan sanksi pidana karena di dalam Pasal tersebut dijelaskan bahwa Penyelenggara wajib menerapkan program anti pencucian uang dan pencegahan pendanaan terorisme, sehingga Penyelenggara turut bersalah karena tidak bisa menjalankan amanat yang dituangkan dalam Pasal tersebut, dan secara tidak langsung Penyelenggara turut bersalah karena platform yang dikelolanya menjadi wadah untuk melakukan pencucian uang maupun pendanaan teroriame.

\section{Problematika Non Normatif}

a. Infrastruktur

1) Platform Penyelenggara

Hingga saat ini belum ada Layanan Urun Dana atau platform Penyelenggara equity crowdfunding yang terdaftar dan berizin dari OJK, karena payung hukum equity crowdfunding yaitu Peraturan Otoritas Jasa Keuangan Nomor 37/POJK.04/2018 tentang Layanan Urun Dana Melalui Penawaran Saham Berbasis Teknologi Informasi (Equity Crowdfunding) baru disahkan dan mulai diberlakukan pada tanggal 31 Desember 2018, sehingga saat ini baru dilakukan peninjauan terhadap PUJK yang ingin menjadi Penyelenggara equity crowdfunding. Diharapkan OJK segera menginformasikan Layanan Urun Dana yang telah terdaftar dan berizin kepada publik sehingga equity crowdfunding dapat segera berjalan di Indonesia, agar semakin banyak perusahaan start up dan UKM yang memanfaatkannya untuk mencari permodalan. 
2) Lembaga Alternatif Penyelesaian Sengketa

Equity crowdfunding dalam penyelenggaraannya menggunakan teknologi informasi, baik dari pendaftaran sampai terjadinya transaksi menggunakan jasa pihak ketiga yaitu Penyelenggara dan menggunakan media teknologi informasi. Sehingga sewajarnya, sengketa yang terjadi di dalam penyelenggaraan equity crowdfunding merupakan sengketa di bidang financial technology, yang membutuhkan tinjauan dari ahli di bidang teknologi informasi. Di dalam Lembaga Alternatif Penyelesaian Sengketa yang bergerak di bidang fintech tersebut, equity crowdfunding harus memiliki anggota yang memahami mengenai pasar modal dan juga memiliki anggota yang memahami mengenai teknologi informasi, sehingga apabila terdapat permasalahan atau sengketa mengenai masalah pasar modal atau masalah mengenai teknologi informasi atau gabungan antara keduanya, maka Lembaga Alternatif Penyelesaian Sengketa fintech dapat mengambil jalan penyelesaian yang dapat menguntungkan kedua belah pihak yang bersengketa.

b. Sistem

Belum adanya aturan dan sanksi yang dapat diberikan OJK apabila ternyata Penerbit tidak menggunakan dana yang telah terhimpun sesuai dengan rencana awal yang diinformasikan melalui platform Penyelenggara. Seharusnya, baik OJK maupun Penyelenggara memberikan sanksi kepada Penerbit yang didapati melakukan usaha yang berbeda dengan yang direncanakan sebelumnya. Karena Penyelenggara berwenang untuk menciptakan sistem yang menguntungkan bagi Penerbit maupun Pemodal, bukan hanya salah satu pihak. Penyelenggara berhak mengatur mengenai kesesuaian rencana yang dirancang oleh Penerbit dengan realisasi penggunaan dananya dan dimasukkan ke dalam perjanjian yang mengikat antara Penyelenggara dan Penerbit.

c. Budaya

1) Sikap Pelaku Usaha

Equity crowdfunding cenderung susah diterima oleh pendiri perusahaan start up maupun UKM karena memiliki ego yang tinggi. Maksud dari ego yang tinggi tersebut adalah jika Penerbit masih merasa kekurangan modal dan ingin menambah permodalannya lagi, dan mengharuskan Penerbit untuk melepaskan saham lagi di Layanan Urun Dana, para pendiri perusahaan tersebut susah untuk membagikan saham yang telah dipegangnya untuk dijual.

Sesuai dengan Pasal 57 POJK Equity Crowdfunding yang menyatakan bahwa:

Penyelenggara harus mendukung pelaksanaan kegiatan yang bertujuan untuk meningkatkan literasi dan inklusi keuangan.

Pasal 14 POJK Nomor 1/POJK.07/2013 tentang Perlindungan Konsumen Sektor Jasa Keuangan, menyebutkan bahwa

Pelaku Usaha Jasa Keuangan wajib menyelenggarakan edukasi dalam rangka meningkatkan literasi keuangan kepada Konsumen dan/atau masyarakat. 
Maka dari itu, Penyelenggara seharusnya dapat berperan aktif dalam memberikan edukasi untuk memperbaiki pola pikir pendiri Penerbit agar Penerbit dapat berkembang dan Layanan Urun Dana dapat terselenggara dengan baik. OJK juga menetapkan rencana penyelenggaraan edukasi tersebut wajib disusun dalam suatu program tahunan dan dilaporkan kepada OJK, dengan maksud agar OJK mengerti langkah apa saja yang dilakukan oleh Penyelenggara agar Penerbit dan Pemodalnya mengalami peningkatan pemahaman dan tingkah laku, dan OJK dapat melakukan kontrol kepada Penyelenggara agar kedepannya juga memberikan pengaruh positif kepada Penggunanya, bukan hanya menyediakan Layanan Urun Dana saja.

2) Laporan Pelaku Usaha

OJK mengatur dan mewajibkan Penyelenggara dan Penerbit dalam equity crowdfunding untuk memberikan laporan kepada OJK. Penyelenggara wajib memberikan laporan tahunan, laporan tengah tahunan dan laporan insidentil kepada OJK, dan Penerbit yang terdaftar dalam platform Penyelenggara equity crowdfunding diwajibkan untuk selalu memberikan laporan tahunan kepada OJK dengan maksud untuk kepentingan pengawasan. Sering kali PUJK tidak melakukan pelaporan sesuai dengan keadaan aslinya, hanya melakukan pelaporan mengenai hal-hal yang dianggap baik untuk dilaporkan sehingga OJK hanya mengetahui bahwa PUJK memiliki kinerja yang baik yang sesuai dengan apa yang seharusnya dijalankan. Selain itu, laporan tersebut berguna bagi Pemodal untuk ikut mengawasi jalannya usaha Penerbit. Di dalam Pasal 35 Ayat 1 huruf h POJK Equity Crowdfunding, OJK hanya mensyaratkan laporan keuangan Penerbit setidaknya disusun berdasarkan standar akuntansi tanpa akuntabilitas publik, maksud OJK menetapkan hal ini adalah untuk memudahkan Penerbit mendaftarkan diri di Layanan Urun Dana. Tetapi hal ini dapat menimbulkan masalah khususnya jika laporan keuangan yang dilakukan Penerbit tidak cukup baik, sehingga dapat menjadi hambatan bagi Pemodal untuk melakukan kontrol terhadap Penerbit.

\section{d. Keterbatasan Pengetahuan Masyarakat}

Equity Crowdfunding bisa dikatakan salah satu alternatif permodalan yang baru masuk dan bertumbuh di Indonesia, sehingga tidak heran jika masih banyak masyarakat Indonesia yang kurang familiar dengan istilah "equity crowdfunding", sehingga cenderung masih sulit untuk menarik Penerbit bahkan Pemodal di equity crowdfunding. Sehingga dalam hal ini, peran sosialisasi yang dilakukan OJK kepada masyarakat menjadi sangat penting untuk mendukung perkembangan sumber daya manusia di Indonesia agar mengenal equity crowdfunding. Selain untuk mengenalkan equity crowdfunding kepada masyarakat Indonesia, peran sosialisasi juga dapat menumbuhkan awareness masyarakat Indonesia terhadap investasi ilegal yang menjamur di Indonesia, khususnya equity crowdfunding ilegal yang mungkin akan dijumpai di kemudian hari. 


\section{Simpulan}

Pelaksanaan equity crowdfunding belum optimal. Hal ini disebabkan adanya problematika dalam aspek normatif dan non normatif. Aspek normatif meliputi: (1) Tidak adanya batasan mengenai sumber daya manusia yang dianggap ahli untuk melakukan reviu terhadap laporan keuangan dan legalitas Penerbit, (2) Tidak adanya standar minimal yang harus dilakukan Penyelenggara apabila Penyelenggara mengajukan permohonan pengembalian izin kepada Otoritas Jasa Keuangan, (3) Tidak adanya pengaturan Penerbit melaporkan realisasi penggunaan dana wajib disertai dengan buktinya, (4) Syarat yang diberikan Otoritas Jasa Keuangan yang mengharuskan Pemodal memiliki kemampuan membeli saham Penerbit dan analisis risiko terhadap saham Penerbit bersifat abu-abu, dan (5) Tidak adanya sanksi pidana. Aspek non normatif antara lain: (1) Infrastruktur, yang mencakup belum adanya platform Penyelenggara, dan Lembaga Alternatif Penyelesaian Sengketa di bidang teknologi informasi, (2) Sistem equity crowdfunding apabila berjalan tidak sesuai dengan rencana kerja Penerbit, (3) Budaya, yang mencakup sikap pelaku usaha, dan laporan pelaku usaha, dan (4) Keterbatasan pengetahuan masyarakat.

\section{E. Saran}

Berdasarkan penelitian yang penulis telah laksanakan, maka penulis dapat memberikan saran-saran sebagai berikut:

1. Otoritas Jasa Keuangan sebaiknya merevisi POJK Equity Crowdfunding yang mengakomodasi: (a) batasan mengenai sumber daya manusia yang dianggap ahli untuk melakukan reviu terhadap laporan keuangan dan legalitas Penerbit, (b) peraturan lebih lanjut dalam hal Penyelenggara mengajukan permohonan pencabutan izin kepada Otoritas Jasa Keuangan, (c) mewajibkan Penerbit melaporkan realisasi penggunaan dana disertai dengan buktinya, (d) Standar Pemodal yang dianggap memiliki keampuan membeli saham dan menganaliisis risiko saham Penerbit, dan (e) pemberian sanksi pidana

2. Otoritas Jasa Keuangan agar: (a) mempercepat pendirian platform equity crowdfunding serta membentuk Lembaga Alternatif Penyelesaian Sengketa di bidang fintech, (b) memberikan kejelasan kepada konsumen equity crowdfunding dan memberikan sanksi pidana atas terjadinya perbedaan antara rencana dan realisasi yang dilakukan Penerbit terhadap usahanya, (c) melakukan penyesuaian laporan yang diberikan oleh PUJK dengan keadaan aslinya, dan (d) melakukan pemberdayaan kepada masyarakat mengenai equity crowdfunding agar layanan equity crowdfunding dapat menjaring banyak masyarakat sehingga mendorong berkembangnya perusahaan start up dan UKM, dan meningkatkan pengetahuan PUJK.

\section{F. Daftar Pustaka}

Buku

Ana Rokhmatussa'dyah dan Suratman. 2011. Hukum Investasi dan Pasar Modal. Jakarta:Sinar Grafika.

Andrian Sutedi. 2014. Aspek Hukum Otoritas Jasa Keuangan. Jakarta:Raih Asa Sukses. 
Dhaniswara K. Harjono. 2007. Hukum Penanaman Modal. Jakarta:PT Raja Grafindo Persada. Peter Mahmud Marzuki. 2014. Penelitian Hukum. Jakarta: Kencana Prenada Media Group. Romli Atmasasmita. 2010. Globalisasi \& Kejahatan Bisnis. Jakarta: Kencana Prenada Media Group.

\section{Jurnal}

Belleflamme, P., Lambert, T., \& Schwienbacher, A. 2013. "Crowdfunding: Tapping the right crowd." Journal of Business Venturing. Belanda:Elsevier.

Gita Widi Bhawika. 2017. "Risiko Dehumanisasi pada Crowdfunding sebagai Akses Pendanaan Berbasis Teknologi di Indonesia." Jurnal Sosial Humaniora. Volume 10, Ed. 1. Surabaya:Fakultas Bisnis dan Manajemen Institut Teknologi Sepuluh November.

Martin Angerer, Alexander Brem, Sascha Kraus, \& Andreas Peter. 2017. "Start-Up Funding via Equity Crowdfunding in Germany - A Qualitative Analysis of Success Factors." Journal of Entrepreneurial Finance. Jerman:University Liechtenstein.

Ethan Mollick. 2015. "The Dynamics of Crowdfunding: An Exploratory Study.” Journal of Business Venturing. Amerika:The Wharton School of the University of Pennsylvania.

Nir Vulkan, Thomas Astebro, \& Manuel Fernandez Sierra. 2015. "Equity Crowdfunding: A New Phenomena." Journal of Business Venturing Insights. Inggris:University of Oxford.

Kannya Purnamahatty Prawirasasra. 2018. "Financial Technology in Indonesia : Disruptive or Collaborative?" Reports on Economic and Finance, Vol.4, 2018, no.2. Jakarta:Ekuitas School of Business.

Rosalina, Handojo, A., \& Wibowo, A. 2012. “Aplikasi Crowdfunding Sebagai Perantara Penggalangan Dana Berbasis Website dan Facebook Application." Jurnal Infra. Komputer, 2 (Jaringan Komputer) 1-5. Surabaya:Universitas Kristen Petra.

Matteo Rossi. 2014. "The New Ways to Raise Capital: An Exploratory Study of Crowdfunding." Sciedu Press. International Journal of Financial Research. Italy:University of Sannio.

Ross S. Weinstein. 2013. "Crowdfunding in the U.S. and Abroad: What to Expect When You're Expecting”. Cornell International Law Journal. New York:Cornell Law School. 